Jarosław KOZUBA, Tomasz WOJNAR, Magda MROZIK, Bartosz STOŁTNY The Silesian University of Technology (Politechnika Ślaska)

\title{
USE OF ELECTRIC MOTORS IN THE CONTEXT OF GLIDER AVIATION
}

\section{Zastosowanie silników elektrycznych w szybownictwie}

\begin{abstract}
In sailplane aviation, I attach great importance to the achieved aerodynamic parameters due to the main idea of sailplane flights, which is the flight of a sailplane without external energy supply for staying in the air and only in favourable weather conditions, e.g. increasing thermal movements of the air. Only during take-off, external devices, such as a winch or a towing plane, can be used. Therefore, the use of a propulsion installed in sailplanes and operating only during take-off is a very convenient solution. This is a step towards facilitating the access to flying for a wider group of people due to the reduction of costs related to the take-off processes, and also increases the level of safety of sailplane flights by enabling the use of propulsion at critical moments of the flight. The study presents the current trends in the development of gliding, in particular motor gliders. Additionally, as a result of research works, the energy storage system was shown, which is the weakest element of the system, and at the same time the one with the greatest development potential.
\end{abstract} Keywords: transport, glider, electric motor, Li-POL cell

Streszczenie: $W$ lotnictwie szybowcowym duża wage przywiazuje się do osiaganych parametrów aerodynamicznych ze względu na główna ideę, jaka jest lot bez zewnętrznego zasilania energia do przebywania $w$ powietrzu $i$ tylko $w$ sprzyjajacych warunkach atmosferycznych, np. zwiększenie ruchów termicznych powietrza. Jedynie podczas startu można korzystać z urzadzeń zewnętrznych, takich jak wyciagarka czy samolot holowniczy. Bardzo wygodnym rozwiazaniem jest zainstalowanie $w$ szybowcach napędu działajacego tylko podczas startu. To krok w kierunku ułatwienia dostępu do latania szerszej grupie osób ze względu na redukcje kosztów związanych z procesami startu, a także zwiększenie poziomu bezpieczeństwa lotów szybowcowych poprzez umożliwienie wykorzystania napędu $w$ krytycznych momentach. W opracowaniu przedstawiono aktualne trendy $w$ rozwoju szybownictwa, w szczególności motoszybowców. Dodatkowo w wyniku prac badawczych wykazano najsłabszy element systemu, a jednocześnie mający największy potencjat rozwojowy - układ magazynowania energii.

Słowa kluczowe: transport, szybowiec, silnik elektryczny, ogniwo Li-POL 


\section{Introduction}

Glider aviation is a specific field of aviation characterized by a very specific structure of an aircraft without propulsion, however, a sailplane pilot is able to stay in the air for long hours under appropriate weather conditions - mainly upward movements related to the phenomenon of uneven heating of the Earth's surface [14], which results in the occurrence of rising air currents, the so-called "thermal chimneys". Despite the ability of machines and pilots to stay in the air for a long time, it is necessary to "initially" raise the machine to the appropriate height at which it is possible to safely continue free flight. For this purpose, winches and towing planes are commonly used [9]. These are the main methods of setting gliders at the appropriate height in order to continue free flight with the sailplane [5]. The main goal of the research was to analyse the current trends in the development of motor gliders, and then to select the most promising direction of development, with an indication of the critical elements of motor glider propulsion systems. For this purpose, a number of studies were conducted consisting in the analysis of the existing solutions, and confronting the obtained information with the data obtained from current scientific works describing new technological solutions in the field of generally understood electrification of transport. Based on the conducted analysis of various scientific studies describing the glider towing process supported by the performed measurements, the value of energy needed to lift a given glider was estimated $[15,19]$. In the research process, attention was paid to the positive aspect of the use of electric drives as the basic propulsion system, which is a compromise solution suitable for the use in modern motor gliders, the results of the analysis are presented in the further part of the study science. The main advantage of using an electric drive is the ease of use and flexible assembly [7]. At the same time, the development of electricity storage technology enables the construction of a propulsion system with parameters sufficient to lift the glider into the air [2, 12]. Currently, the best choice are variations of lithium cells due to the high density of stored energy per mass and their natural feature of not having a memory effect that shortens the life of existing electrical energy sources $[2,21]$. Along with the development of energy storage techniques, attempts are made to use alternative energy sources based on hydrogen technology, but despite its mainly ecological values, it is treated by producers as a curiosity or technology demonstrator [1]. Built drives are based on BLDC motors with permanent magnets and electronic commutation [4, 7]. The most common control elements are modern inverters using advanced control algorithms and sensors installed in the motor housing $[3,6]$.

\section{The classification of the electric propulsion's elements in the motor gliders}

The presented publication outlines the results of research works related to the list of current trends in the development of motor sailplanes $[5,16]$. By analyzing the available 
theoretical materials or scientific studies related to the construction of motor gliders and comparing them with the currently produced motor gliders, it can be concluded that nowadays, propulsion systems based on the technique of electric drives are increasingly used $[9,13]$. These systems consist of three main parts, i.e.:

- Electric drive - usually a BLDC motor

- Motor Driver - usually a vector inverter

- Energy storage - usually a cell package.

\subsection{Electric drive}

Electric engine is the main element. Currently, propulsion engines, used as BLDC (Brushless Direct-Current motor) engines, are applied. The construction is characterized by the lack of the commutator element which improves the energy efficiency of the engine eliminating the losses related to the commutation process of the certain winding terminal and the loss of the elements of brushes, which are made of materials with worse electric parameters. It could be the dissipation of the BLDC energy, because of high-voltage sintered and bonding magnets. In the case of BLDC engines, because of the usage of sintered or bonding magnets, the energy loss is noticeable in the majority of elements which conduct the electricity, that is in the coil harness, which are usually made of copper, so the material which has excellent thermal conductivity and thanks to which it is relatively simple to transfer the heat energy from the system $[3,6]$. Additional advantage of such construction is the lack of the spark effect on the elements of the commutator, which in spite of the very simple construction generates quite a lot of problems related to the necessity of using suitable brushes which are made of the material that matches exactly the demand for energy of the particular construction, that is why, it is difficult to obtain the universal construction [7]. Having the commutator with the brushes is related to the necessity of carrying out the periodic maintenance works which is connected to maintenance, or, alternatively, replacing the commutator and especially brushes, which are designed for relatively short time of operation in the case of the dimension optimization.

Another important feature of such construction is putting the coils in the engine housing and thanks to that, the process of transferring the generated heat directly to the environment without the necessity of extorting additional ventilation is expedited. Due to that, there is a possibility to get more density of air in the coil. The next very important fact which characterizes electric engines is the lack of elements which have a short life span that have a direct influence on the life span. In the case of BLDC engines, the only element which has a direct influence on the life span is the usage of rotor bearing, that is why in the case of using the professional installation of the best quality bearings and thanks to the maintenance of suitable conditions, especially the temperature; it is possible to get very long time of malfunction-free operation, which many times exceeds the life span construction in which a particular engine operates.

Using the electric engines is better than combustion engines, which means that electric engines have substantially more efficiency than combustion ones. 
Due to the fact that the efficiency of the combustion engines is rarely higher than $40 \%$, and additionally, the work conditions which are the effect of installation in the glider negatively affect the efficiency of the combustion units. However, the efficiency of the typical electric engines could fall within $85 \%-95 \%$, and even in big constructions, it is possible to make models with the efficiency of $99 \%$ (the ABB-based synchronous engine). While the constructions that could be used in aviation have the efficiency of $80 \%-95 \%$ [20].

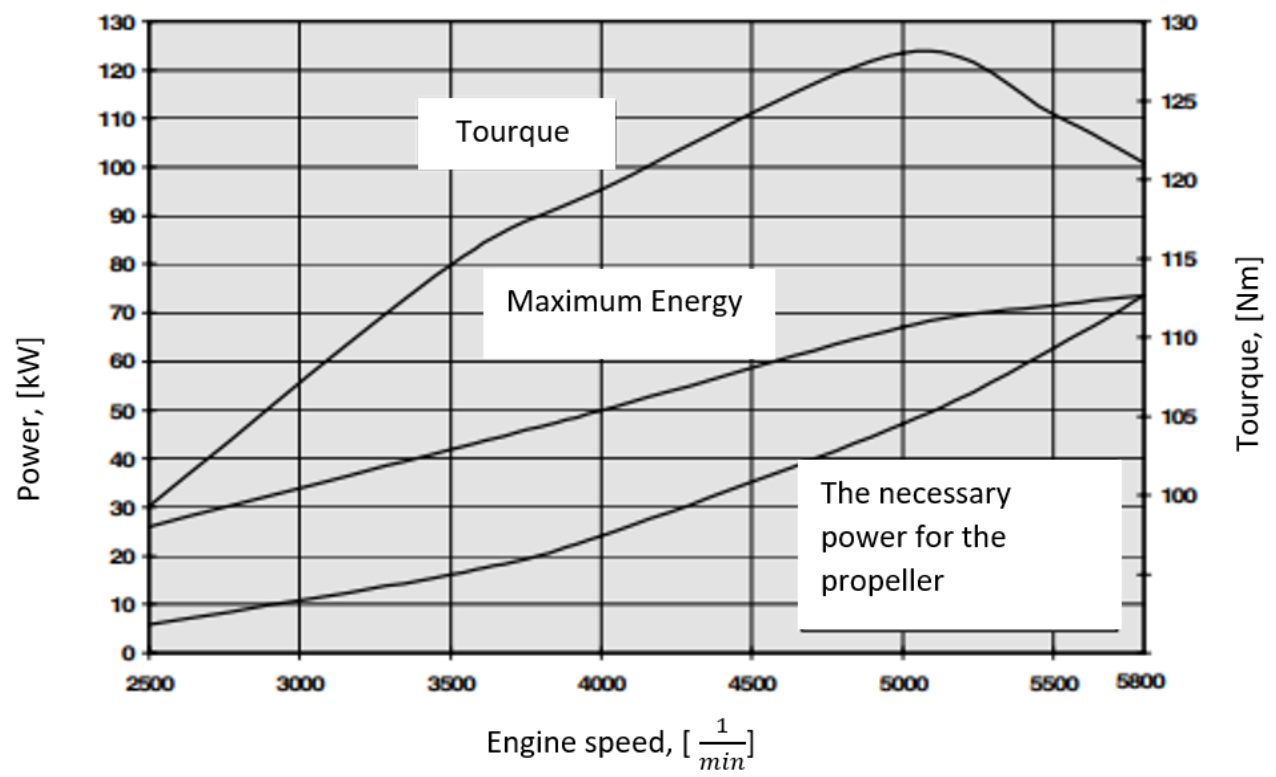

Fig. 1. A description of the combustion engine Rotax912 [11]

That is an effect of choosing the type of construction and moreover, the possibility of controlling the engine when it is needed and aside from the optimal working time. In spite of using the engines which have a little lower motor's parameters, the electric ones are still minimum twice better than combustion units in this case.

Due to the fact that these engines are narrow in scope when we would say about the socalled "an engine rotation" (fig. 1). The comparison of both engines shows that the combustion units could not be better than the electric units [11].

\subsection{Motor driver}

An essential element of the electric propulsion is the engine controller which gives the opportunity to power the engine and at the same time, it allows for warming up and the changing the rotation number, and therefore, it is possible to change the thrust. Due to the fact that the BLDC engines are used, we need a 3-phase power controller, so there is a need to use frequency inventers fitted to the engine's character parameters [7]. Nowadays, we are 
able to build relatively small frequency inventers, which weigh little, and are able to control the engines that enable the glider take-off and have several dozen kilowatts.

There are two methods of controlling the BLDC engines:

- controlling with the use of a position sensor

- or sensor free controlling.

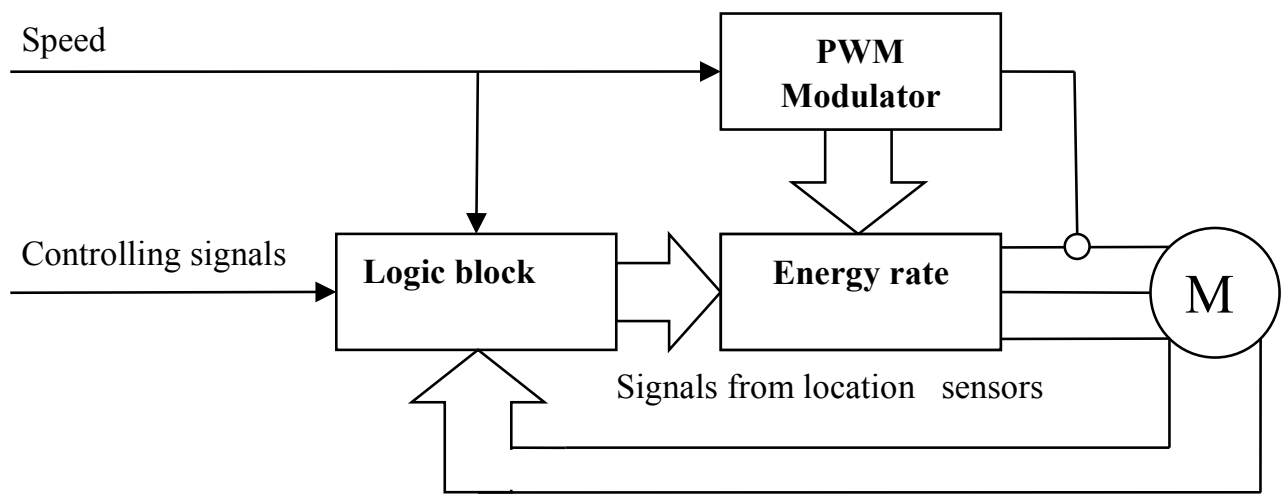

Fig. 2. A block diagram of controlling the BLDC engines

A block diagram of controlling BLDC engines which uses the location sensors is presented in fig. 2. It is a classic control system which is equipped with the location sensors of bearing towards to the stator. Mostly, the location sensors are used as the elements that detect the magnetic induction field strength around a sensor (commonly called the Hall effect sensors). The main control signal is the signal which gives the speed effect, which runs directly into the PWM system. The PWM modulation has to generate the suitable power stage signal in order to make the regulator error the lowest. That is why, the feedback for a phase voltage of the generated engine mileage is possible.

Furthermore, the main regulator signals could be distinguished:

- Regulation of rotations

- Start/Stop

- Brake

- Signals of advanced settings.

The appropriate way to control the regulator's signals enables to change the rotation's regulation, that is, it allows for taking off, stopping the engine, emergency stopping of an engine and more advanced options: the way of warming op/ emergency braking of the engine and various kinds of options which give the opportunity to use the engines in individual applications.

These blocks, which were described above, are the blocks which could be one of the logic elements and we have to carry out analysis of numbers, which were connected to the way of regulation. However, the power stage is the main block, and, in this case, the executive elements are the power electronics systems which can generate three phase electric power directly to the engine, thanks to the appropriate regulator's signals and the 
constant voltage. These are the high voltage key elements and they are usually used in the topology of the three phase H-bridge. In the following graph, we have presented the scheme of the transistor keys.

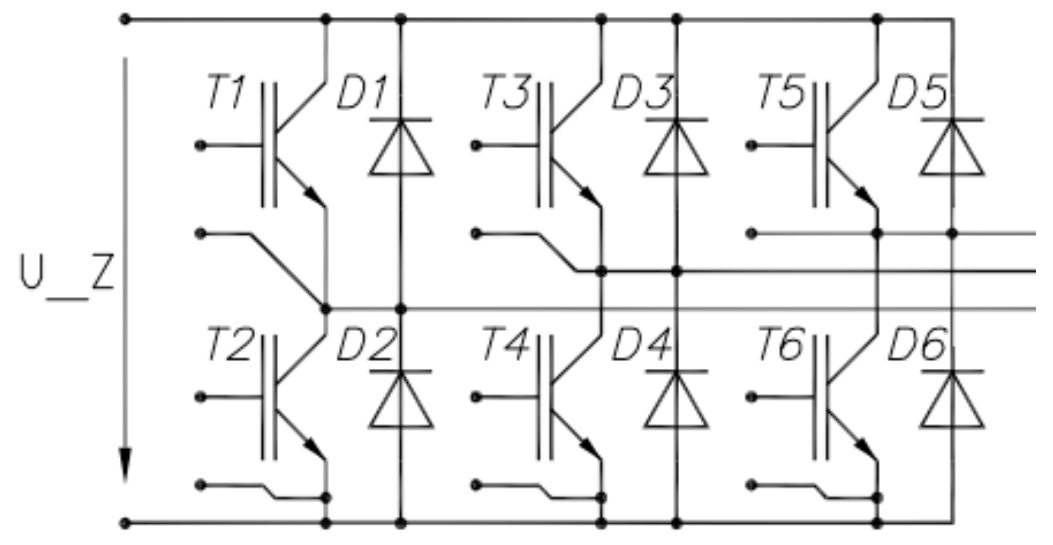

Fig. 3. The types of transistor keys, $3 \mathrm{f}$ configuration

The elements that differ both ways of regulation are the elements of the position's regulation. When we use such regulation's sensors, there is a possibility to regulate the engine's rotations almost from zero value, and at the same time, we do not lose the value of the generated rotation's moment. The elements could be assembled inside the engine and, that is why, these elements have no influence on the engine's dimension. However, such solution has a few disadvantages, mostly the fact that the electric heating coil has an influence on the location sensors - because the Hall effect sensors have an essential influence on the worsening of the positioning accuracy. That is why, people often install the location sensors in a separated chassis beyond the main body of the engine and that fact solves the problems with variable temperature and an operation of high value variable's inductance which is produced in the stator's coils. A better solution, which is not sensitive to the variable values of induction, is using the optical location sensors; this solution is increasingly used in modern solutions with regard to high repeatability of measurement and the possibility to change the location while the engine is working. Another asset of this solution is a considerably longer life span of that sensor type with regard to sensors which use the Hall effect. In the case of a sensor less control, the location and the speed of the engine determine themselves indirectly by means of current and voltage measurement. Additionally, in this type of control, the subsequent subgroups could be distinguished:

- one which uses the electromotive force SEM,

- the other which uses the current and the voltage measurement and equations which describe the machine,

- the last subgroup uses the motion blur control and neutral network 
a)

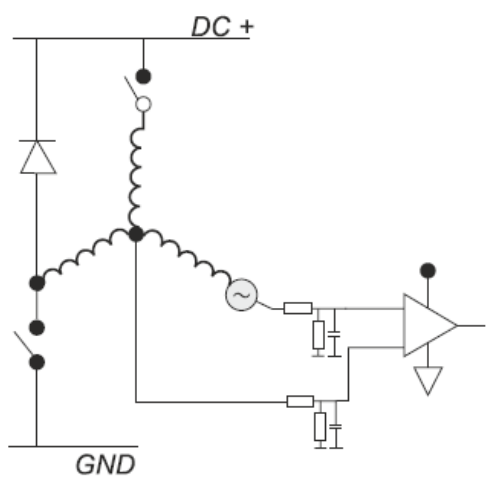

b)

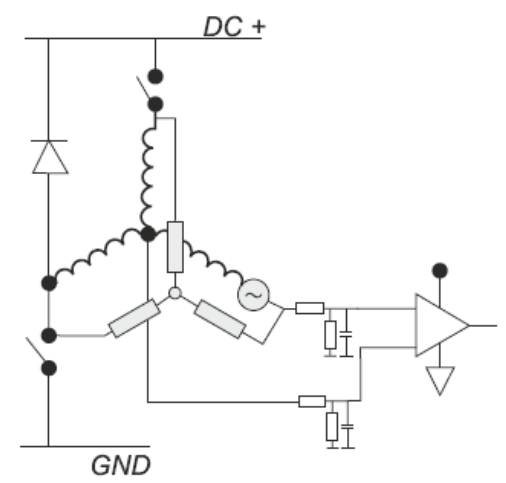

Fig. 4. SEM detection system: a) with a neutral point, b) system which uses an artificial neutral point

In the method which uses SEM, the detection of passing through zero is possible due to the unpowered coil's phase. If the neutral phase is not led the artificial neutral point is used, both cases are presented in fig. 3. In case of passing through zero point of the SEM interphase point, it is possible to control the engine easily. The basic method and, at the same time, the simplest, is observing the voltage of neutral point, so the commutation of subsequent phase; there is a need to wait until the engine rotation will reach $30^{\circ}$. This value is usually determined based on the engine's rotation speed. However, this basic method has an essential defect, because due to the SEM value, it is possible to use it within the range of $10-100 \%$ of the rotation's value of the engine and because of that, we lose the possibility to control in the lower rotation range.

If a mathematical model is used to control the engine, we have to be aware of huge computational expense for the control processor and, that is why, this method requires an implementation of the very fast microprocessor's systems, which convert, in real time, mostly complicated mathematical models of the engine. Such a model needs to describe, in a very precise way, how the engine works and, the physical constants which characterize the particular engine, that is: stator resistance, inductance of the particular phases, magnetic flux and so on. This method gives excellent results, but unfortunately, it is very sensitive to distortions of all kinds caused by imperfect implementation of the production spread of particular elements and material wear during operation. In order to prevent the influence on the fluctuation parameters, we use adaptive methods which help to analyze the changes of parameters which occur and minimize the influence of these variables on the systems' modus operandi. When the mathematical models have the complex constructions or if it is not possible to make the model which sufficiently reflects the construction, we use blur regulators which are based on the straightforward rules in the specific air conditions. They are less sensitive to distortions and are more dynamic.

When we deal with many cases of the propulsion operation, in the particular air conditions, there is a possibility to use neutral networks and due to that the controller is tentatively ready to work, whereas during all-day work, it works in the learning mode and, 
at the same time, it adapts to the centre of the engine, in which it works. This solution is friendly to the human beings because it adapts behaviours and habits presented by an operator. However, changing the way of control through the factory settings could be problematic.

Thanks to the usage of the modern controllers, which have very fast microprocessor systems, which are made of microprocessors signals, we can control the engines in a sensor less mode and such resolution considerably simplifies the construction of the engine and simultaneously it causes the desired effect of the dimension and weight reduction with the certain amount operations. Thanks to the rotation regulation of the drive motors, there is a possibility to modulate the thrust and to adjust it to the presented demands. A big engineering problem during constructing the BLDC engines, used as the main propulsion, is the high current, which flows in the circumferences (for example the $30.5 \mathrm{~kW}$ engine, which is powered by the Li-Pol links, which final voltage is $105 \mathrm{~V}$ ). In order to get the full power, the controller drains from the source $305 \mathrm{~A}$ of the continuous current and due to that, we are able to get $92 \mathrm{~kg}$ static thrust, which is measured on the surface of the earth. The measurements were done on the tested GP14 SE electric motor glider during the ground attempts. That is why, it is essential to produce the high current circuit paying particular attention to the quality of the workmanship of the joints and, at the same time, minimizing the points which have increased the resistance. The most problematic point are the all kinds of disjoints which are inevitable because of the safety requirements. The next source of the high release of heat are the electric elements of commutation, which are made on the basis of MOSFET or IGBT transistors. These transistors have an excellent parameter (mostly the drain resistance when it is open - values are comparable to copper). However, during the commutation process, the energy losses increase along with the increase of the drain current and the switching frequency. In order to get the smooth running of the engine, there is a need to use the maximal permissible frequency of clocking the key transistors.

\subsection{Energy storage}

Currently, the element which restricts construction engineers to the mass installation of the propulsion is the source of power supply because the current sources of power are characterized by the low density of the energy expressed per mass unit. In comparison with the electric links, in addition, Zinc-Air and Lithium-Air, are currently tested or are being prepared to be used on an industrial scale and, that is why, using them with the commercial purpose is not possible now. However, these are two types of links and we have to pay special attention to the commercialization of high operating sources of the energy, which successfully could replace the liquid fuel used in aviation, at this point in time $[19,21]$. While comparing the petrol's energy density and currently used Li-Pol links, the energy source, if we use the example mentioned above of this type of propulsion, it is usually Li-Pol links or lithium ion. One of the problems, which should be dealt with, is to make an attempt of using all kinds of an electric power, such is wasting the elements, which conduct the energy. Especially, the parameter of internal resistance determines the usefulness for 
the particular technology. That is why, the main problem, that the constructors have to deal with, is an exaggerated generating of the energy, which causes problems with ensuring the appropriate operation conditions for the links and the modules of BMS (Battery Management System) systems.

Table 1

The energy density of the chosen fuels and links

\begin{tabular}{|l|c|c|}
\hline \multicolumn{3}{|c|}{ Energy density } \\
\hline & {$[\mathbf{k W h} / \mathbf{k g}]$} & {$[\mathbf{k W h} / \mathbf{l}]$} \\
\hline Liquid hydrogen $\left(-250^{\circ} \mathrm{C}\right)$ & 33 & 2,4 \\
\hline Liquid methanol & 5,6 & 4,4 \\
\hline Liquid petrol & 13 & 8,7 \\
\hline Li-Pol links & $0,2-0,3$ & $0,25-0,35$ \\
\hline Zn-Air links & 0,4 & \\
\hline Li-Air links & 11,5 & \\
\hline
\end{tabular}

Because of the high capacity, we usually use active BMS modules which realize the functionality of the single link's load which are balancing, and function as the protection against the temperature rising, too big charging / discharging the current and temperature rise, and they care of the appropriate propulsor voltage level during the charging and deep discharging $[2,18]$.

\section{Using the own propulsion - discussion}

Due to the own propulsion, it is possible to use the motor gliders in the easier way. The key step of the motor gliders' flight is taking off, where it is necessary (in most cases) to use the external devices to raise it up high enough to continue the independent flight, while using aerodynamics conditions, which occur during the flight. The installation of the own propulsion for the motor glider enables to independently take off of such device and then after achieving the desired ceiling, it could be stopped or in order to improve the aerodynamics, there is a possibility to hide the external propulsion elements away (the engine, the inverter and the propeller) into the fuselage; of course, when the motor glider's construction gives such opportunity or if the propulsion is prepared for that. The motor gliders which are built currently, thanks to the considerable improvement of the aerodynamics in comparison to the previous constructions, are characterized by low power requirements during take-off, which significantly enables to increase the size of the possible engines. Thanks to the example given above, we are able to resign from the internal combustion engine in favor of the electric ones. Additionally, the electric engines are characterized by the better flexibility in operation and maintenance, and thanks to the modern cells, they offer an alternative to the internal combustion engines $[5,16]$. 
For example, the parameters of the typical, modern construction of the motor gliders which are produced by PESZKE S.C. company- GP14-SE model. Using the Li-Pol links VTC6 produced by SONY company with the capacity of $4.6 \mathrm{kWh}$ and using the propulsion engine with the capacity of 30,5 (the power was measured during the grounds tests), which enables to achieve the rate of climb of $6 \mathrm{~m} / \mathrm{s}$ and this fact enables to get about $500 \mathrm{~m}$ (typical air winches are characterized by the ability to ascend the towing aircraft at $300-600 \mathrm{~m}$ high) [10].

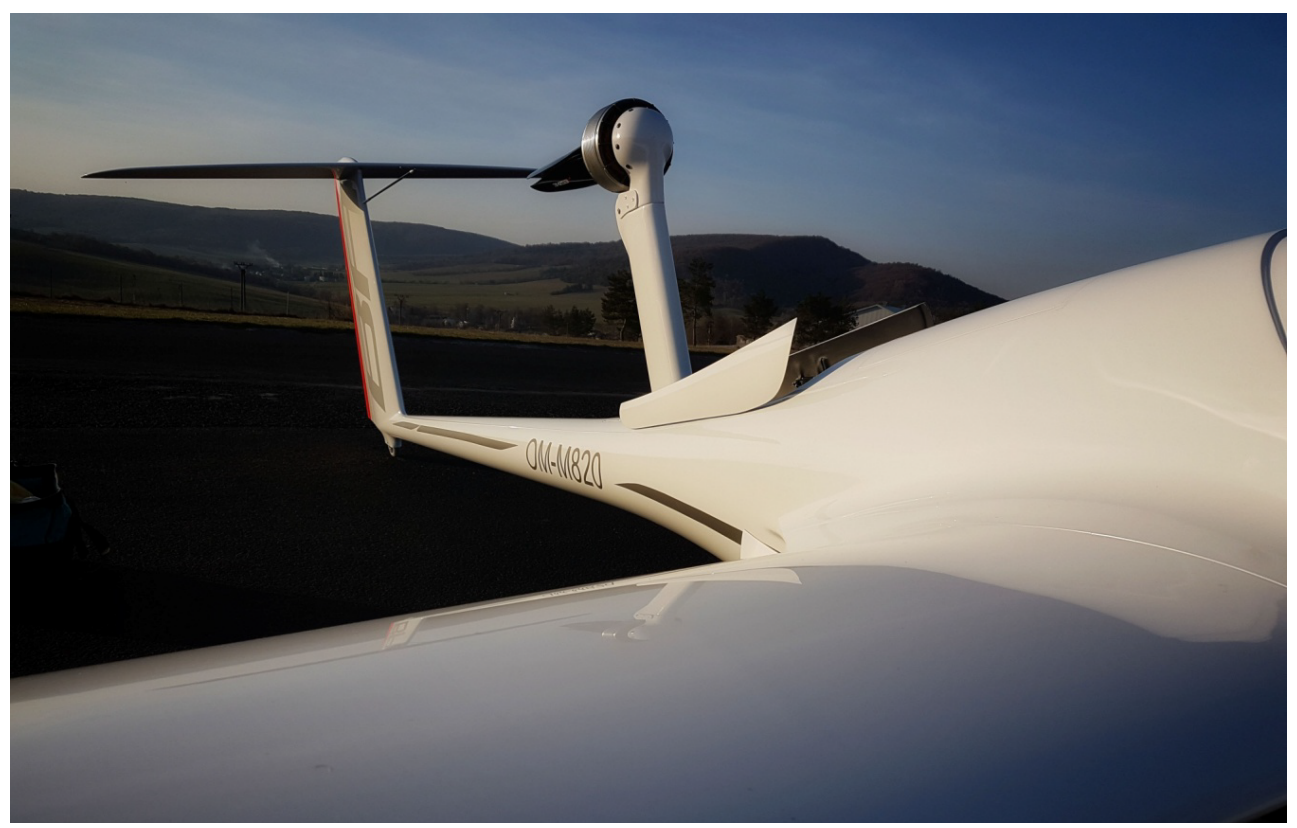

Fig. 5. The electric motor glider GP14 SE, produced by Peszke S.C. company [10]

\section{Conclusions}

The ongoing trend of the development of technology, which uses the electric energy as the alternative to the fossil fuels, leads to the development of almost every kind of the life field, including the development of aviation. Unfortunately, the efficiency of the wide range of the power sources (mostly lithium polymer) is not productive enough in comparison with using the conventional fuels in order to use them interchangeably. Customized product design problem is often solved by parametric modeling [22]. However, technological progress, connected with the development of the electric links, gives new opportunities to use electric propulsion in fields where the demands for the high amount of energy are considerably restricted. This is the example of this using electric propulsion which perfectly harmonizes with the idea of gliding. 
The application of coordinated propulsion has many advantages that include:

- the ability of self-reliant take off of the motor glider,

- increasing the safety due to the ability to link the propulsion in the case of the low cruising altitude between the thermals,

- the ability to avoid an influence on the considerable power which has the percussion character on the motor gliders' construction connected to the process of towing behind the winch or the airplane,

- the ability to create an additional air stream which blows the control system of the motor glider during its take off, and it significantly enhances control at lower speeds; that fact, during the aviation courses, raises the security level while flying.

- Additionally, using the electric propulsion, has the following advantages of the propulsions mentioned above:

- the easiness to make the systems to be integrated (using the chosen power supplies, an inventor, an engine and propellers),

- the modular construction of the system enables an easy way to adapt the system to the existed constructions,

- almost linear characteristic of the operation of electric engines,

- longer life span of the propulsion unit,

- a constant weight independent of the battery level,

- the lack of exhaust fumes - (environmental aspect),

- low operating cost,

- ease of servicing,

- the lack of elements with a short life span,

- a quiet work of the propulsion system - the generated noise is caused mostly by the propeller and, moreover, these propulsions could be used wherever we want to minimize the integration to the environment.

Despite many advantages, which were mentioned above, the main problem related to using the electric propulsion systems, is namely, a relatively low density of energy per one unit. This is currently the biggest problem of such solutions. However, as we can observe in the presented example, the currently produced electronic motor gliders compete on the market with the classic solutions successfully. The additional advantage is the intensive development of the technology of electric power storing, which is the "weakest link" of the system and an implementation of the new generation of coils, and does not have to be integrated in the other parts of the propulsion system. That is why we have to pay special attention to aviation as the most developmental and peculiar ground for testing and later, implementing the developed solutions, which require more energy reserves, namely commercial aviation or military aircraft. 


\section{References}

1. Czarnocki P., Dudek M., Drabarek K., Frączek W., Iwański G., Miazga T., Nikoniuk M., Raźniak A., Rosół M.: Electric motor-glider powered by a hydrogenfuel cell stack. MATEC Web of Conferences 304, 03011, 2019.

2. Czerwiński A.: Akumulatory, baterie, ogniwa. Warszawa 2005.

3. Dencer A., Glinka T., Jakubiec M., Polak A.: Bezszczotkowy silnik prądu stałego sposoby sterowania komutatorem elektronicznym. Zeszyty Problemowe - Maszyny Elektryczne Nr 65/2003, BOBRME Komel Katowice 2003.

4. Domoracki A., Krykowski K.: Silniki BLDC-klasyczne metody sterowania. Zeszyty Problemowe, Maszyny Elektryczne, nr 72, Politechnika Śląska, Gliwice 2005.

5. Fehrenbacher J., Stanley D.L., Johnson M.E., Honchell J.: Electric Motor \& Power Source Selection for Small Aircraft Propulsion. College of Technology Directed Projects. Paper 33, 2011.

6. Glinka T.: Maszyny elektryczne wzbudzane magnesami trwałymi. Wydawnictwo Politechniki Śląskiej, 2002.

7. Goryca Z.: Bezszczotkowe silniki prądu stałego - konstrukcje i sterowanie. 2013

8. Górecki P.: Akumulatory i nie tylko... Elektronika Praktyczna, 3/2015.

9. http://front-electric-sustainer.com/contact.php

10. http://www.gpgliders.com.

11. Instrukcja użytkowania silnika Rotax 912.

12. Jaroszyński L.: Akumulatory litowe w pojazdach elektrycznych. Przegląd Elektrotechniczny 08/2011.

13. Keskin G., Durmus S., Kafali H., Osmangazi E., The developments in electric-powered motor gliders. International Symposium on Electric Aviation and Autonomous Systems, 26-29 May 2019.

14. Kurski W.: Analiza sił i prędkości podczas startu szybowca za wyciągarką. Lisie Kąty 2008.

15. Leme Galvao F.: A Note on Glider Electric Propulsion. Technical Soaring, Vol. 36, No. 4, 2012.

16. Otto Reimers J.: Introduction of electric aviation in Norway. Feasibility study assigned by: Avinor - Norwegian administrator of state-owned airports and navigation service, NLF - Norwegian Airsport Federation NHO Luftfart - Federation of Norwegian Aviation Industries, represented by SAS and Widerøe 22 March 2018.

17. Shanhai Ge, Yongjun Leng, Teng Liu, Ryan S. Longchamps, Xiao-Guang Yang, Yue Gao, Daiwei Wang, Donghai Wang and Chao-Yang Wang: A new approach to both high safety and high performance of lithium-ion batteries. Science Advances, Vol. 6, No. 9, 2020, DOI 10.1126/sciadv.aay7633.

18. Shi Q., Sheng G.: Electrolyte for lithium ion battery. CN103594729A, 2014.

19. Siedlecki M., Galant M., Fuć P., Lijewski P.: Porównanie parametrów użytkowych akumulatorów w technologii litowo-jonowej stosowanych w układach napędowych pojazdów elektrycznych. Logistyka, No. 3, 2015. 
20. www.abb-conversations.com/p1/2017/11/9905-wydajnosci-silnika-rekord-swiata-abb.

21. www.batteryspace.com/LiFePO4/LiFeMnPO4-Batteries.aspx

22. Zdravković M., Korunović N.: Novel methodology for real-time structural analysis assistance in custom product design., Facta Universitatis, Series: Mechanical Engineering, DOI 10.22190/FUME200828008Z. 